\title{
Comparative Study of The Concept of Religiusity in The Western and Islamic Perspective
}

\author{
Tri Yaumil Falikah a,1,* \\ *a Universitas Ahmad Dahlan, Indonesia \\ 1 tri.falikah@pai.uad.ac.id \\ *Correspondent Author
}

Received: August 22, 2021

\section{KAT A KUNCI}

Religiusity

Western

Islamic

Perspective

\begin{abstract}
Religiusitas sering dikaitkan dengan perwujudan keyakinan atau agama dari seseorang maupun kelompok baik dalam bentuk penghayatan maupun pengamalan ajaran-ajarannya. Seringkali para peneliti menggunakan aspek-aspek yang mengambil dari teori Barat (Glock \& Stark) di mana dalam proses perumusannya berpijak pada teori dari agama tertentu (kristen). Seiring berjalannya waktu, adanya kekhususan pada responden dari kalangan muslim, maka teori dari Barat tersebut oleh salah seorang peneliti diadaptasi ke dalam teori religiusitas yang lebih bernuansa Islami. Namun, Hal tersebut mendapat sorotan dari peneliti lain terutama peneliti yang menginginkan adanya rumusan tersendiri terkait dengan aspek religiusitas dalam pandangan Islam bukan sekedar adaptasi dari teori Barat kemudian dicari persamaan dengan Islam akan tetapi lebih menekankan pada ciri khas daripada Islam itu sendiri untuk mengukur tingkat religiusitas para penganutnya. Religiusitas Islami yang dipakai selama ini merupakan teori yang mengadaptasi dari teori Barat. Konsep religiusitas ini digunakan untuk mengukur tingkat religiusitas umat Muslim dan sudah diujikan pada responden dengan jumlah yang banyak serta dimodifikasi dengan kajian-kajian yang lebih Islami.
\end{abstract}

ABSTRAK

This is an open-access article under the CC-BY-SA license.

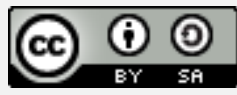

\section{Introduction}

Religiusitas dapat dikatakan sebagai nilai-nilai agama yang masuk ke dalam diri manusia, sehingga memainkan peranan utama dalam upaya pengembangan karakter manusia. Hal itulah yang menjadi sebab mengapa dalam sejarah bangsa-bangsa di dunia, banyak agama mengajarkan kebajikan adalah semacam perwujudan cita-cita untuk membuat orang-orang jujur dan soleh di masa depan (Safrilsyah et al., 2010). Saling menghormati, menghargai antar sesama manusia, dan memberi pertolongan merupakan nilai-nilai yang ditanamkan oleh setiap agama di dunia. Semua ajaran agama memiliki tujuan yang sama, yaitu kedamaian dan anti 
kekerasan, saling tolong-menolong dan memaafkan. Karena itu semua agama yang ada di muka bumi ini mengajarkan kebaikan dan kedamaian hidup manusia (Hanafi, 2001).

Islam memiliki dasar dalam memandang religiusitas sebagaimana disebutkan dalam alQuran Surah al-Baqarah ayat 177:

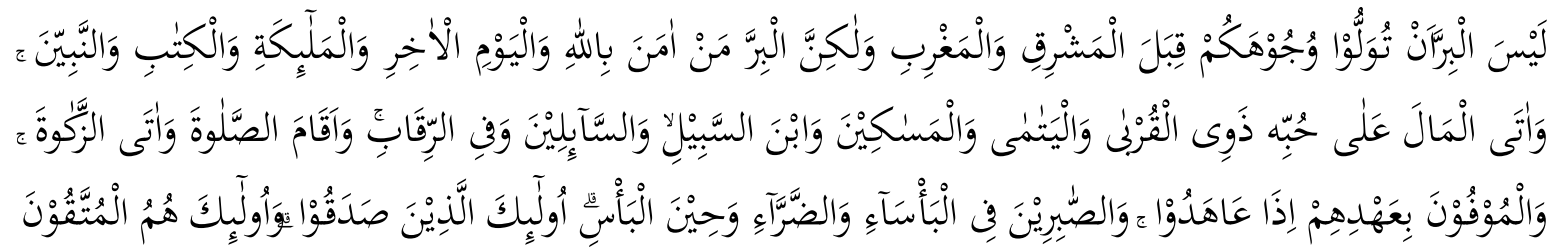

Artinya: Kebajikan itu bukanlah menghadapkan wajahmu ke arah timur dan ke barat, tetapi kebajikan itu ialah orang yang beriman kepada Allah, hari akhir, malaikat-malaikat, kitab-kitab, dan nabi-nabi dan memberikan harta yang dicintainya kepada kerabat, anak yatim, orang-orang miskin, orang-orang yang dalam perjalanan (musafir), peminta-minta, dan untuk memerdekakan hamba sahaya, yang melaksanakan salat dan menunaikan zakat, orang-orang yang menepati janji apabila berjanji, dan orang yang sabar dalam kemelaratan, penderitaan dan pada masa peperangan. Mereka itulah orang-orang yang benar, dan mereka itulah orangorang yang bertakwa (Q.S. Al-Baqarah : 177) (Departemen Agama Republik Indonesia, 2017).

Melalui Firman Allah di atas, ada penjelsan yang dapat kita ambil bahwa yang dimaksud dengan kebajikan atau ketaatan bukanlah sekedar menghadapkan wajah dalam shalat ke arah timur dan barat tanpa makna, tetapi kebajikan yang sesungguhnya ialah berpegang teguh pada keimanannya dan beramal shaleh kepada sesamanya. Dalam mengkaji konsep religiusitas, saat ini kita bisa menelaahnya dari dua perspektif (barat dan Islam) dimana dari kedua perspektif tersebut tentu ada hal-hal yang saling beririsan dan ada pula sisi yang memiliki perbedaan. Teori dari Glock \& Stark saat ini sering dijadikan sebagai salah satu referensi bagi para peneliti untuk menelaah konsep religiusitas menurut pandangan ilmuan barat. Sedangkan dari sisi pandangan Islam kita bisa mengambil dari hasil kajian beberapa peneliti sebelumnya yang pernah membahas mengenai konsep religiusitas dalam perspektif Islam (Aviyah, 2013).

Beberapa hasil penelitian sebelumnya yang membahas mengenai religiusitas diantaranya penelitian dari Safrilsyah, dkk (2010) menyimpulkan bahwa selama ini ilmuan barat (khususnya psikolog) melihat religiusitas sebatas apa yang dilihat dan diukur secara material dan angka-angka. Berbeda halnya dengan religiusitas dalam Islam yang tidak sebatas dari apa yang terlihat dari ekspresi tingkah laku keberagamaan seorang muslim. Namun juga lebih jauh lagi memahami ajaran Islam dan memaknai segala kehidupan dalam rangka ibadah kepada Allah (Safrilsyah et al., 2010). Kemudian dari hasil penelitian Fridayanti (2016) memaparkan dalam simpulannya bahwa para psikolog muslim di beberapa negara telah memulai upaya 
untuk mengembangkan skala penelitian religiusitas yang berbasis tradisi dan pengajaran Islam, namun upaya yang lebih giat diperlukan untuk terus menyempurnakan skala religiusitas tersebut agar dapat menggambarkan khasanah Islam secara komprehensif termasuk yang dapat menggambarkan pula sisi atau dimensi spiritualitas Islam sebagai bagian dari religiusitas (Fridayanti, 2016b).

Annisa Fitriani (2016) melalui penelitiannya berjudul Peran Religiusitas dalam Meningkatkan Psychological Well Being menemukan kesimpulan bahwa semakin baik komitmen religiusitas seseorang maka semakin baik pula tingkat hubungan dengan lingkungannya karena dengan berbagai aktivitas keagamaan maka dapat meningkatkan rasa solidaritas kelompok dan memperkuat ikatan kekeluargaan sehingga akan meningkatkan Psychological Well Being (Fitriani, 2016). Pada tahun yang sama, mengunggah hasil penelitian mereka dalam sebuah jurnal yang membahas tentang Perbedaan dan Persamaan antara Konsep Religiusitas dan Spiritualitas. Hasil penelitian mereka menyimpulkan bahwa Religiusitas memiliki dasar keyakinan teologi (Ketuhanan) sesuai dengan agama tertentu, memiliki pedoman mengenai cara, metode dan praktek ibadah, dan berfungsi membantu individu memahami pengalaman-pengalaman hidupnya. Sebaliknya, spiritualitas tidak memiliki dasar keyakian teologis maupun praktek ibadah tertentu, tetapi memiliki fungsi membantu individu memahami pengalaman hidupnya (Amal, 2017).

Ada pula penelitian terbaru yang dilakukan oleh Subhan El Hafiz yang memberikan rekomendasi sebagai berikut; (1) mempromosikan penggunaan istilah "religiusitas" untuk kajian yang melihat aspek pengaruh agama dalam diri seseorang, (2) Mendorong studi yang lebih komprehensif terhadap skala-skala religiusitas, (3) Dibutuhkan kajian yang lebih intensif untuk memastikan bahwa definisi yang dihasilkan dalam penelitian menggambarkan religiusitas subjek yang diteliti, (4) Mendiversifikasi responden penelitian agar tidak hanya melakukan penelitian pada kelompok responden tertentu, (5) Mengkaji religiusitas pada konsep-konsep yang lebih detail untuk memahami inkonsistensi dari temuan-temuan terdahulu (El Hafiz, 2019). Beberapa hasil penelitian sebelumnya yang sudah dibahas di atas, menjadi sebuah acuan bagi penulis untuk ikut melengkapi penelitian tentang religiusitas. Akan tetapi pada penelitian kali ini penulis bermaksud mengembangkan variabel yang akan diteliti dengan cara mengkomparasikan (membandingkan) konsep Religiusitas dalam perspektif barat dan perspektif Islam.

\section{Method}

Metode penelitian yang digunakan adalah jenis penelitian kualitatif. Menurut Sugiyono, metode penelitian kualitatif adalah metode penelitian yang berlandaskan pada filsafat 
postpositivisme, digunakan untuk meneliti pada kondisi obyek yang alamiah, (sebagai lawannya eksperimen) dimana peneliti adalah sebagai instrumen kunci, pengambilan sampel sumber data dilakukan secara purposive dan snowball, teknik pengumpulan dengan triangulasi (gabungan), analisis data bersifat induktif atau kualitatif, dan hasil penelitian kualitatif lebih menekankan makna daripada generalisasi (Arikunto, 2007) (Sugiyono, 2013).

Pengumpulan data pada penelitian ini menggunakan studi pustaka. Studi pustaka merupakan metode pengumpulan data yang diarahkan kepada pencarian data dan informasi melalui dokumen-dokumen, baik dokumen tertulis, foto-foto, gambar, maupun dokumen elektronik yang dapat mendukung dalam proses penulisan."Hasil penelitian juga akan semakin kredibel apabila didukung foto-foto atau karya tulis akademik dan seni yang telah ada." (Moleong, 2010). Analisis data kualitatif adalah bersifat induktif, yaitu suatu analisis berdasarkan data yang diperoleh, selanjutnya dikembangkan menjadi hipotesis (Arikunto, 2007). Berdasarkan hipotesis yang dirumuskan berdasarkan data tersebut, selanjutnya dicarikan data lagi secara berulang-ulang sehingga selanjutnya dapat disimpulkan apakah hipotesis tersebut diterima atau ditolak berdasarkan data yang terkumpul. Bila berdasarkan data yang dapat dikumpulkan secara berulang-ulang dengan teknik triangulasi, ternyata hipotesis diterima, maka hipotesis tersebut berkembang menjadi teori (Hardani. Ustiawaty, 2017).

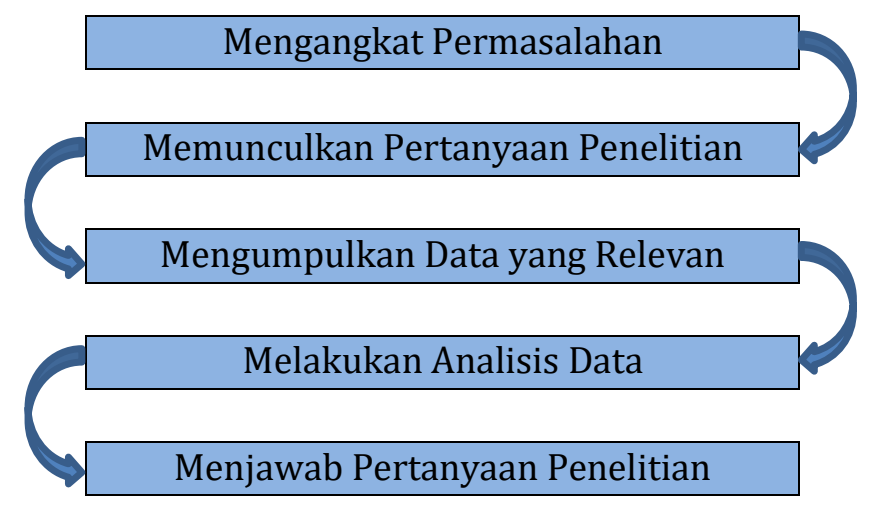

Fig 1. Tahapan dalam penelitian (Arifin, 2011):

\section{Results and Discussion}

Istilah religiusitas berasal dari kata religi (religio, bahasa latin; religion, bahasa Inggris), dan kata ini sudah kita kenal yang berarti agama, dan din (al-diin, bahasa Arab) (Nashori, F. N., Mucharam, R. D., \& Ru'iya, 2002). Sedangkan Agama menurut Nasution dalam Jalaludin mengandung arti ikatan yang harus dipegang dan dipatuhi manusia. Ikatan yang dimaksud tersebut berasal dari suatu kekuatan yang lebih tinggi dari manusia sebagai kekuatan gaib yang 
tak dapat ditangkap dengan pancaindera, namun mempunyai pengaruh besar sekali terhadap kehidupan manusia sehari-hari (Jalaluddin, 2005).

Melalui Kamus Besar Bahasa Indonesia (KBBI) kata religiusitas memiliki arti pengabdian terhadap agama atau kesalehan. Sementara kata beragamaan memiliki akar kata 'beragama'. Kata beragama memiliki tiga makna yaitu menganut agama, taat kepada agama, dan mementingkan agama (Fridayanti, 2016a). Terdapat dua hal yang menjadi ciri dari religiusitas (Amir, 2016); Pertama, Religiusitas memiliki dasar-dasar teologi yang berasal dari ajaran atau doktrin agama tertentu. Kedua, Religiusitas memiliki metode, cara, atau praktek ibadah yang diajarkan oleh institusi agama.

Dalam aktivitas sehari-hari, seseorang akan melakukan sesuatu yang dilandasi oleh nilai yang terkandung dalam ajaran agamanya (Ru'iya, 2013). Secara terperinci menyebut ada delapan fungsi agama dalam kehidupan seseorang, antara lain:

1. Fungsi Edukatif: Maksudnya yaitu agama yang menjadi keyakinan seseorang memberikan ajaran-ajaran yang harus mereka patuhi baik itu berupa perintah maupun larangan. Kedua hal tersebut di arahkan oleh agama agar seorang pribadi dapat melakukannya sehingga dia menjadi manusia yang baik menurut ajaran agamanya.

2. Fungsi Penyelamat: Fungsi ini merupakan tujuan utama manusia memeluk suatu agama, karena setiap manusia mendambakan keselamatan baik keselamatan dalam kehidupan didunia terlebih kehidupan setelah kematian yang menjadi keyakinan dalam setiap agama.

3. Fungsi Pendamai: Melalui agama seseorang mendapat kedamaian batin, terlebih bagi mereka yang bersalah atau berdosa. Rasa bersalah atau dosa akan segera hilang jika orang yang memeluk agama tertentu melakukan ritual tertentu sesuai dengan agamanya sebagai upaya penebusan dosa, seperti bertobat, penebusan dosa atau pensucian.

4. Fungsi Kontrol Sosial: Para penganut agama sesuai dengan agama yang dianutnya akan terikat batin kepada tuntunan ajaran agamanya tersebut, baik secara pribadi maupun secara kelompok. Ajaran agama bagi pemeluknya dianggap sebagai norma, sehingga dalam hal ini agama berfungsi sebagai pengawasan social secara individu maupun sosial.

5. Fungsi Pemupuk Rasa Solidaritas: Para penganut agama yang sama secara psikologis akan merasa memiliki kesamaan dalam satu kesatuan iman dan kepercayaan. Rasa kesatuan ini akan memupuk rasa solidaritas dalam kelompok maupun perorangan.

6. Fungsi Transformatif: Ajaran agama dapat merubah kehidupan kepribadian seseorang atau kelompok menjadi kehidupan baru sesuai dengan ajaran agama yang dianutnya. Kehidupan baru yang diterima ini berdasarkan agama yang dipeluknya kadang kala mampu merubah kesetiaannya kepada suatu aturan tertentu seperti adat. 
7. Fungsi Kreatif: Ajaran agama mendorong dan mengajak para penganutnya untuk bekerja produktif bukan saja untuk kepentingan dirinya sendiri, tetapi juga untuk kepentingan orang lain. Penganut agama tidak hanya disuruh untuk bekerja rutin dalam pola hidup yang sama, tetapi juga dituntut untuk melakukan inovasi dan penemuan baru.

8. Fungsi Sublimatif: Ajaran agama juga mensakralkan segala bentuk usaha manusia, tidak saja yang bersifat keagamaan (ukhrawi), tetapi juga yang bersifat duniawi. Segala usaha manusia selama tidak bertentangan dengan norma-norma agama, jika diniatkan dengan tulus untuk mencari ridha Tuhan akan mempunyai nilai ibadah.

Salah satu teori dari Barat yang hingga saat ini sering digunakan sebagai acuan untuk mengukur tingkat religiusitas adalah teori dari Glock \& Stark (1965). Menurut Glock \& Stark, religiusitas dipandang sebagai komitmen religius yang dimiliki oleh individu, terkait agama dan keyakinan, dan terlihat dari perilaku individu tersebut dalam melaksanakan ritual agama dan keyakinan iman yang dianut. dimana pada teori tersebut dijelaskan ada lima macam dimensi keberagamaan yaitu (Glock, C \& R, 1965):

1. Dimensi Intelektual (Knowledge): dimensi ini merujuk pada ekspektasi sosial bahwa orang yang religius memiliki pengetahuan tentang agamanya dan mereka dapat menjelaskan pandangannya terkait dengan agama itu sendiri. Indikator umum untuk dimensi ini adalah frekuensi berpikir tentang masalah-masalah agama.

2. Dimensi Ideologi: dimensi ini merujuk pada ekspektasi sosial bahwa individu yang religius memiliki kepercayaan terkait eksistensi dan esensi dari kenyataan transendental dan relasi antara transenden dan manusia. Dimensi ini terkait sejauh mana individu menerima dogma agamanya dan mempercayainya.

3. Dimensi Ritualistik (Practice): dimensi ini merujuk pada tingkatan individu melakukan kewajiban-kewajiban ritual agamanya. Dimensi ini terdiri dari dua yaitu pelaksanaan di publik dan pelaksaan saat sendiri. Pelaksaan publik merujuk pada ekspektasi sosial dimana individu yang religius memiliki partisipasi dalam kegiatan komunitas keagamaan. Manifestasinya dapat dilihat dari partisipasi dalam ritual dan aktivitas komunal. Indikator dimensi ini terkait dengan frekuensi seseorang dalam menjadi bagian dari pelayanan keagamaan. Sementara pelaksanaan ritual saat sendiri, individu yang religius akan mengabdikan diri pada transendensi dalam aktivitas dan ritual individu di ruang privat.

4. Dimensi Perasaan (Feeling): dimensi perasaan atau dimensi pengalaman merujuk pada pengalaman-pengalaman individu yang ia anggap melakukan komunikasi dengan Tuhan. Suatu hal yang terjadi dipercayai oleh individu merupakan tanda dari Tuhan. Pengalaman baik maupun buruk dipercayai terjadi atas kuasa Tuhan, dan pengalaman ini 
memengaruhi individu secara emosional.

5. Dimensi Konsekuensial: dimensi konsekuensial menyatakan bahwa individu yang religius menunjukkan perilaku yang konsekuen dengan ajaran agamanya. Dimensi ini melihat sejauh mana individu melakukan hal sesuai dengan perintah agamanya dan menjadikan agama sebagai pedoman dalam melakukan tindakan sehari-hari (Dewi, 2012).

Al-Attas (1981) memaparkan konsep religiusitas yang terlahir dari istilah din dalam Islam berbeda dengan konsep religiusitas Barat. Secara ringkas, istilah din mengandung empat makna, yaitu 1) keberhutangan, 2) kepatuhan, 3) kekuasaan bijaksana, dan 4) kecenderungan alami atau tendensi. Keempat makna ini memiliki keterikatan makna dengan iman, kepercayaan-kepercayaan (akidah) dan praktek-praktek ajaran yang dianut oleh seorang muslim dalam kehidupannya sehari-hari (kepribadian muslim) (Rafiyanti Paramitha Nanu, 2021).

Dalam Islam, religiusitas pada garis besarnya tercermin dalam pengamalan akidah, syariah, dan akhlak, atau dengan ungkapan lain: Iman, Islam, dan Ihsan. Bila semua unsur itu telah dimiliki oleh seseorang, maka dia itulah insan beragama yang sesungguhnya. Di dalam buku ilmu jiwa agama, Dradjat mengemukakan istilah kesadaran agama (religious consciousness) dan pengalaman agama (religious experience). Kesadaran agama merupakan segi agama yang terasa dalam pikiran dan dapat diuji melalui introspeksi, atau dapat dikatakan sebagai aspek mental dari aktivitas agama. Pengalaman agama adalah unsur perasaan dalam kesadaran agama, yaitu perasaan yang membawa kepada keyakinan yang dihasilkan oleh tindakan (Jalaludin, 2012).

Ancok dan Suroso (2011) mengelaborasikan dimensi-dimensi dalam tipologi Glock dan Stark dengan ajaran Islam, dan menurut mereka tipologi tersebut merupakan rumusan teori yang sangat brilian karena mampu menjelaskan konsep beribadah secara menyeluruh dimana dalam ajaran Islam, kaum Muslim diajarkan untuk melibatkan seluruh aspek kehidupannya dalam beribadah kepada Allah. Dimensi religiusitas tersebut dapat dijelaskan sebagai berikut (Ancok, Djamaludin dan Suroso, 2011):

1. Dimensi ideologis/keyakinan (akidah), sejauh mana seorang muslim mempercayai ajaran-ajaran yang sifatnya fundamental dan dogmatis dalam Islam. Dalam Islam, dikenal dengan Rukun Iman; iman kepada Allah, iman kepada Malaikat, iman kepada Rasul, iman kepada Al Quran, iman kepada hari akhir dan iman kepada takdir.

2. Dimensi intelektual/pengetahuan (Ilmu), sejauh mana pengetahuan yang dipahami oleh setiap Muslim berkaitan dengan dasar-dasar keyakinan, ritual, kitab suci (sejarah dan hukum Islam) dan tradisi-tradisi yang dilakukan. 
3. Dimensi ritual/praktik agama (syariah), sejauh mana seorang Muslim mematuhi perintah untuk menjalankan ibadah. Dimensi ini mencakup perilaku pemujaan, ketaatan dan halhal lain yang dapat menunjukkan komitmen terhadap agaman yang dianutnya. Misalnya sholat lima waktu, membaca ayat suci Al Quran, berpuasa Ramadhan, dan lain-lain. Aspek ini juga tercermin dalam bagaimana implikasinya dalam kehidupan bermasyarakat, misalnya tata cara pernikahan, menyambut kalahiran anak dan lain sebagainya.

4. Dimensi penghayatan/eksperiensial, berkaitan dengan pengalaman-pengalaman keagamaan, persepsi, perasaan dan sensasi yang dirasakan ketika melihat maupun melakukan komunikasi, dalam suatu esensi ketuhanan, dengan Tuhan, kenyataan terakhir, dengan otoritas transendental.

5. Dimensi konsekuensial/pengamalan (akhlak), bagaimana seorang Muslim berperilaku di dunia sekuler dengan di motivasi oleh nilai religiusitas internal. Dapat diibaratkan bahwa dimensi ini merupakan hasil dari proses identifikasi terhadap keyakinan keagamaan, praktek, pengalaman, dan pengetahuan seseorang yang diekspresikan dalam tindakan perilakunya sehari-hari.

Adaptasi terhadap aspek-aspek religiusitas dari Glock \& Stark untuk digunakan dalam pengukuran religiusitas Islami ternyata mendapat sorotan dari Kraus yang menyatakan bahwa Glock dan Stark dalam menentukan aspek religiusitasnya berpijak pada agama Kristen, padahal religiusitas Islami sangat berbeda dengan agama tersebut. Islam mempunyai kekhususan dalam beberapa hal diantaranya adalah pandangan dalam tauhid, misalnya, pendapat dalam agama-agama Islam cara pendang mereka hanya bersifat keduniawian yang bersifat materi, sementara tauhid dalam Islam memandang kehidupan ini jauh dan tidak hanya bersifat duniawi tetapi juga bersifat ukhrawi atau metafisik (King, P.E. \& Boyatzis, 2004).

Kraus mengistilahkan pandangan religiusitas menurutnya secara khusus yaitu religiusitas Islami. Religiusitas Islami merupakan tingkat kesadaran akan Tuhan yang dimengerti menurut pandangan tauhidiah Islam, berperilaku sesuai dengan kesadaran tersebut, atau tingkat manifestasi terhadap kesadaran akan Tuhan dalam kehidupan sehari-hari yang dipahami melalui ajaran Islam sunni (Dewi, 2012). Kraus telah membuat sebuah konstruk skala religiusitas yang cukup teruji, yaitu dengan jumlah responden yang banyak, serta berdasarkan kajian-kajian lebih Islami (tidak sekedar adaptasi) dari beberapa pendapat sebelumnya. Menurutnya, religiusitas Islami terdiri dua dimensi.

Pertama, Islamic worldview (pandangan terhadap Islam yang lebih dikenal dengan akidah dan tauhid); aspek ini meliputi tiga sub aspek, yaitu creator and creation, existence and transcendence, dan all-encompassing religion. 
1. Creator and creation. Aspek ini dirancang untuk menilai hubungan antara manusia dan Tuhan-manusia sebagai bentuk tertinggi dari penciptaan dan Allah sebagai Pencipta segala. 'Pencipta dan ciptaan' mencerminkan unsur-unsur inti dari paradigma tauhid dan menilai pemahaman seseorang tentang ketergantungan pada Allah sebagai pemelihara dari semua kehidupan. Aspek ini sebagai indikator pemahaman seseorang tentang hubungan antara manusia dan Tuhan, menyiratkan kesadaran akan Tuhan.

2. Existence and transcendence. Aspek ini terdiri dari pernyataan tentang realitas tak terlihat berdasarkan pengetahuan inderawi. Ini termasuk elemen kunci dari enam tauhid, yaitu akhirat, hari kiamat, para malaikat, pahala dan hukuman; kelangsungan eksistensi setelah kematian, dan alam kehidupan setelah kehidupan di dunia. Aspek ini bertujuan untuk menilai pemahaman spiritual dari peristiwa dan realitas kesadaran spiritual dan nonragawi yang berbeda sesuai dengan perspektif Islam. Realitas seperti itu adalah prinsip utama dari suatu pandangan tauhid yang memandang realitas alam ghaib dan pahala serta hukuman sebagai sebuah kenyataan yang akan dialami setelah kematian.

3. All encompassing religion. Aspek ini bertujuan untuk menilai pemahaman tentang Islam sebagai agama untuk semua, situasi waktu dan tempat. Untuk mengungkap ini, aspek ini item-item yang dibuat terkait dengan: fitrah (keadaan alami manusia); universalitas ajaran Islam; penerapan hukum Islam dan sunnah (jalan) Nabi, penerapan ajaran Islam di dunia modern usia, dan lain-lain. Aspek ini mencakup sub-item yang berhubungan dengan penerapan ajaran Islam yang universal, yang bertindak sebagai indikator untuk pandangan yang konsisten dan pendekatan untuk hidup, konsisten dengan paradigma tauhid dan akidah Islam.

Kedua, Religious personality (Kepribadian agamis). Aspek ini meliputi tiga sub aspek, yaitu Self (self-directed), Social (interpersonal - interactive) dan Ritual (formal worship).

1. Self (self-directed). Aspek ini bertujuan untuk menilai diri sendiri dalam perjuangannya untukberlandaskan Islam. Aspek internal diantaranya adalah kebajikan dan kejahatan seperti kerendahan hati, kesederhanaan, keberanian, kasih sayang, kejujuran, kecemburuan, iri ketenangan, dan lain-lain. Aspek ini diungkap melalui pernyataan pada sikap, motivasi, emosi dan praktekpraktek atau perilaku. Dimensi ini merupakan hubungan seseorang dengan Allah berdasarkan kondisi diri seseorang.

2. Social (interpersonal - interactive). Aspek ini bertujuan untuk menilai aspek sosial dan interpersonal berbasis agama yang upaya pribadi dari perspektif Islam. Ini mencakup kemampuan untuk memahami, bekerja dengan dan berhubungan dengan tetangga, keluarga, seagama dan lain-lain. Aspek ini juga mengukur sejauh mana seseorang merespons motivasi, suasana hati, dan perasaan orang lain. Secara khusus, aspek ini 
meliputi mereka yang membangun interpersonal yang konsisten dengan kepribadian agama Islam seperti yang didefinisikan oleh Al-Qur'an, Sunnah (jalan Nabi). Aspek ini merupakan hubungan seseorang dengan Allah berdasarkan perilaku seseorang terhadap orang lain dan seluruh ciptaan.

3. Ritual (formal worship). Aspek ini bertujuan untuk menilai perjuangan pribadi yang terkait dengan ibadah mahdah atau ritual Islam. Berbeda dengan dua dimensi sebelumnya, dimensi ritual mencerminkan hubungan langsung seseorang dengan Allah melalui tindakan ritual seperti shalat, puasa, membaca Al-Qur'an, amal dan lain-lain. Aspek ini juga mencakup ketaatan kepada disiplin Islam eksternal seperti pakaian dan penampilan seseorang, serta item khusus untuk aturan hukum Islam. Aspek ini bertujuan untuk menilai tingkat komitmen seseorang terhadap perjuangan berislam secara kaffah.

Table 1. Persamaan Dimensi Religiusitas Barat dan Islam

\begin{tabular}{cc}
\hline Barat & Islam \\
\hline Dimensi Ideologis & Keyakinan (Akidah) \\
Dimensi Intelektual & Pengetahuan (Ilmu) \\
Dimensi Ritual & Praktik Agama (Syariah), \\
Dimensi Eksperiensial & Penghayatan (Tasawuf) \\
Dimensi Konsekuensial & Pengamalan (Akhlak) \\
\hline
\end{tabular}

\section{Conclusion}

Religiusitas memiliki beberapa fungsi bagi manusia yaitu; Fungsi Edukatif, Fungsi Penyelamat, Fungsi Pendamai, Fungsi Kontrol Sosial, Fungsi Pemupuk Rasa Solidaritas, Fungsi Transformatif, Fungsi Kreatif, dan Fungsi Sublimatif. Konsep religiusitas dari Glock \& Stark merupakan salah satu teori dari Barat yang merumuskan dimensi religiusitas menjadi lima, yaitu; Dimensi Intelektual (knowledge), Dimensi Ideologi, Dimensi Ritualistik (practice), Dimensi Perasaan (feeling), dan Dimensi Konsekuensial. Sedangkan dimensi religiusitas dalam Islam adalah; Islamic Worldview (Pandangan terhadap Islam yang lebih dikenal dengan akidah dan tauhid) yang memiliki tiga sub aspek yaitu creator and creation, existence and transcendence, dan all-encompassing religion. Religious personality (Kepribadian agamis) yang juga memiliki tiga sub aspek yaitu Self. Ancok dan Suroso merumuskan dimensi religiusitas Glock \& Stark yang mempunyai kesesuaian dengan Islam ke dalam lima dimensi yaitu; Dimensi ideologis/keyakinan (akidah), Dimensi intelektual/pengetahuan (Ilmu), Dimensi ritual/praktik agama (syariah), Dimensi penghayatan/eksperiensial, dan Dimensi konsekuensial/pengamalan (akhlak). Perbedaan konsep religiusitas Barat dengan Islam adalah aspek religiusitas yang ditentukan oleh Glock \& Stark berpijak pada agama Kristen, padahal religiusitas Islami mempunyai kekhususan dalam beberapa hal diantaranya adalah 
pandangan dalam tauhid, tingkat kesadaran akan Tuhan, dan keimanan.

\section{References}

Amal, M. (2017). PERANANAN K.H. AHMAD DAHLAN DALAM PENGEMBANGAN ISLAM. UNIVERSITAS ISLAM NEGERI ALAUDDIN, 53(9), 1689-1699.

Amir, Y. (2016). RELIGIUSITAS DAN SPIRITUALITAS: KONSEP YANG SAMA ATAUBERBEDA? Jurnal Ilmiah Penelitian Psikologi: Kajian Empiris \& Non-Empiris, 2(2), h.67.

Ancok, Djamaludin dan Suroso, F. N. (2011). No TitlePsikologi Islami. Penerbit Pustaka Pelajar.

Arifin. (2011). Metode Penelitian Kualitatif, Kuantitatif, dan R\&D. Alfabeta.

Arikunto, S. (2007). Prosedur Penelitian Suatu Pendekatan Praktek (Revisi VI). Rineka Apta.

Aviyah, E. (2013). Religiusitas, Kontrol diri dan Kenakalan Remaja. Jurnal Psikologi Indonesia, Vol. 3 No.

Departemen Agama Republik Indonesia. (2017). Al-qur'an dan Terjemahannya. Sinar Baru Algesindo.

Dewi, T. K. (2012). THE IDEOLOGICAL DIMENSION OF RELIGIOSITY: IS IT PRIMARILY EXPRESION OF RELIGIOSITY? Triana. Fakultas Psikologi Universitas Airlangga, November 2012, 2-11.

El Hafiz, S. (2019). Subhan El Hafiz [PDF] dari uhamka.ac.id Religiusitas dan Moralitas: Teori Hukuman Tuhan untuk Meningkatkan Peran Agama dalam Moralitas. Jurnal Ilmiah Penelitian Psikologi: Kajian Empiris \& Non-Empiris, Vol. 5, No, 105-112. file://C:/Users/LENOVO/Downloads/62-Article Text-155-1-10-20200227.pdf

Fitriani, A. (2016). Peran Religiusitas dalam Meningkatkan Psychological Well-being. Al-Adyan Jurnal Studi Lintas Agama, 11(1), 1-24.

Fridayanti, F. (2016a). Religiusitas, Spiritualitas Dalam Kajian Psikologi Dan Urgensi Perumusan Religiusitas Islam. Psympathic : Jurnal Ilmiah Psikologi, 2(2), 199-.

Fridayanti, F. (2016b). Religiusitas, Spiritualitas Dalam Kajian Psikologi Dan Urgensi Perumusan Religiusitas Islam. Psympathic: Jurnal Ilmiah Psikologi, 2(2), 199-208. https://doi.org/10.15575/psy.v2i2.460

Glock, C \& R, S. (1965). Religious And Society In Tension. Rand McNally.

Hanafi, H. (2001). Agama, Kekerasan, dan Islam Kontemporer. Jendela.

Hardani. Ustiawaty, J. A. H. (2017). Buku Metode Penelitian Kualitatif dan Kuantitatif (Issue April).

Jalaluddin. (2005). Psikologi Agama. Rajawali Press.

Jalaludin. (2012). Psikologi Agama. PT. Raja Grafindo Persada.

King, P.E. \& Boyatzis, C. (2004). Exploring Adolescent Spiritual and Religious Development; Current and Future Theoretical and Empirical Perspectives. Applied Developmental Science, 8, 2-6.

Moleong, L. J. (2010). Metodologi Penelitian Kualitatif. PT Remaja Rosdakarya.

Nashori, F. N., Mucharam, R. D., \& Ru'iya, S. (2002). Mengembangkan Kreativitas dalam Persepektif Psikologi Islam. Menara Kudus.

Rafiyanti Paramitha Nanu. (2021). Pemikiran Syed Muhammad. Naquib Al-Attas Terhadap Pendidikan di Era Modern. Jurnal Tarbawi, 05(02), 14.

Ru'iya, S. (2013). PENGARUH RELIGIUSITAS ISLAMI TERHADAP PEMAAFAN PADA REMAJA Studi Kasus Di Madrasah Aliyah Negeri III Yogyakarta. Al-Misbah (Jurnal Islamic Studies), 1(1), 61-89. https://doi.org/10.26555/almisbah.v1i1.79 
Safrilsyah, S., Baharudin, R., \& Duraseh, N. (2010). Religiusitas Dalam Perspektif Islam: Suatu Kajian Psikologi Agama. In SUBSTANTIA: Jurnal Ilmu-IImu Ushuluddin (Vol. 12, Issue 2, pp. 399-412).

Sugiyono, D. (2013). Metodelogi Penelitian Kuantitatif, Kualitatif Dan R\&D. Alfabeta.

Vink, R. M., van Dommelen, P., van der Pal, S. M., Eekhout, I., Pannebakker, F. D., Klein Velderman, M., Haagmans, M., Mulder, T., \& Dekker, M. (2019). Self-reported adverse childhood experiences and quality of life among children in the two last grades of Dutch elementary education. Child Abuse \& Neglect, 95, 104051. https://doi.org/10.1016/j.chiabu.2019.104051 